devices with the same object in view, consisting of small channels or shafts brought up from the top of the reservoir to the seat of the lamp flame, are adopted in some American lamps. If these openings or channels were protected, in accordance with the well-known principles which govern the construction of miners' safety lamps, so as to preclude the possibility of flame passing them, they would obviously be unobjectionable, and indeed in one or two instances of modern lamps the openings which have been provided for the escape of expanding air or vapour are of such dimensions that flame could not pass. A simple arrangement which would effect the desired object with perfect safety, and would at the same time protect the lamp wicks from deterioration by the grosser impurities sometimes contained in portions of a supply of oil, is to attach to the bottom of the burner a cylinder of wire gauze of the requisite fineness (twenty-eight meshes to the inch) which would contain the wicks, and would allow the passage of air or vapour through it towards the burner, while it would effectually prevent the transmission of fire from the lamp-flame to the air-space of the reservoir.

Some of the more prominent points elicited by the inquiry in progress, as to the causes of explosions in petroleum lamps, and the conditions which regulate their efficiency and safety, having now been noticed, it remains to offer a few simple suggestions, attention to which cannot but serve to reduce the risks of accident which attend the use of petroleum and parafin oil :-

I. It is desirable that the rıservoir of the lamp should be of metal. It should have no opening or feeding place in the reservoir, nor should there be any opening or channel of communication to the reservoir at or near the burner, unless protected by fine wire gauze, or packed with wire, or unless it is of a diameter not exceeding $0^{\circ} \mathrm{O} 4$ inch.

2. The wick used should be of soft texture and loosely plaited; it should fill the entire space of the wick-holder, and should not be so broad as to be compressed within the latter; it should always be thoroughly dried before the fire, when required for use. The fresh wick or wicks should be but little longer than sufficient to reach to the bottom of the reservoir, and should never be immersed to a less depth than about one-third the total depth of the reservoir.

3. The reservoir or lamp should always be almost filled before use.

4. If it be desired to lower the flame of the lamp for a time, this should be carefully done, so as not to lower it beneath the metal work deeper than is absolutely necessary ; but it should be borne in mind that even then the combustion of the oil will be imperfect, and that vapour of unconsumed petroleum will escape, and render the lamp very unpleasant in a room.

5. When the lamp is to be extinguished, and is not provided with an extinguishing arrangement (of which many excellent forms are now applied to lamps) the flame should be lowered until there is only a flicker; the mouth should then be brought to a level with the top of the chimney, and a sharp puff of breath should be projected across the opening. The lamp should remain on a firm support when it is being extinguished.

The lecturer hopes that, pending the more thorough treatment of this subject by Mr. Redwood and himself when these investigations are completed, the points dealt with in this discourse which relate to accidents wilh petroleum lamps may, on the one hand, tend to dispel groundless alarm as to the dangerous nature of petroleum and paraffin oil as illuminants, and may, on the other hand, serve to convey some useful information respecting the causes which lead to accidents with lamps and the readiness with which they may be avoided.

\section{DR. KLEIN ON CHOLERA}

$A^{\mathrm{T}}$ a recent meeting of the Abernethian Society of St. Bartholomew's Hospital, Dr. Klein briefly reviewed the accepted theories as to the rtiology of cholera, and stated the views concerning it which he had been led to adopt since his visit to India. His address is of importance as embodying the conclusions of the Indian Commission of Inquiry into this disease. Two main theories are held with regard to the cholera - the one, which is supported by a large section of the Indian medical staff, being that cholera is non-infectious and non-communicable; the other, which is upheld by European authorities, heing that it is both infectious and communicable. In support of the former theory may be ouoted the numerous cases of sporadic cholera which occur, and the fact that when troops are attacked in a military cantonment and are at once marched out into camp, no new cases occur other than those which are already incubating. Lastly, in many places in India, in spite of all conditions favourable to a spread of cholers by the evacuations, it is rare for any but sporadic cases to occur. In support of its communicability and infectiousness it is unquestionable that when an outbreak of cholera has occurred, it has in most instances been introduced frum a district where cholera was rife, as instanced by the late outbreak at Marseilles, which was shown to have been introduced from Egypt. Some have maintained that it may be conveyed by winds; against this may be adduced the fact that epidemics have occurred in Malta without any occurring at the same time in Gozo. Now, Gozo is nearer to Egypt than Malta, and yet no epidemic at Malta has cver been preceded by an epidemic at Gozo. The upholders of the theory of infectiveness are divided into two schools-the contagionists, who consider that the disease is directly communicable from the sick to the healthy, and that the virus is contained in the discharges from the alimentary canal; and the localists, who believe that the evacuations contain a germ which is capable of elaborating the virus under suitable conditions of climate and soil. Against the contagionists' view must be considered especially these facts-that it is very rare for attendants to be attacked early, and that they only succumb at a late period of the epidemic ; and that cholera patients are treated in the general wards of a large hospital in Calcutta, and yet no cases of contagion have occurred. Dr. Koch, in studying this disease, found that the lower parts of the small intestine of patients who died from cholera swarmed with peculiar bacilli (comma bacilli), which passed out with the evacuations, and which he considered were capable of manufacturing the cholera virus when introduced into the small intestine of an unhealthy patient. He also believes that this bacillus is destroyed by the acid secretion of the stomach of a healthy person, and, further, that this bacillus is destroyed by drying; and hence that this disease could not be propagated by soiled linen after this had been dried. The German Commission believes these bacilli to be the cause of the disease. Dr. Klein, by a series of experiments, has proved that these comma bacilli are not destroyed by an acid solution of the same strength as that of the gastric juice; but that, on the contrary, they thrive after having been immersed in such a solution. Further, that though these bacilli, in common with all germs (except spores of bacilli), are destroyed by thorough and scientific drying, still soiled linen never becomes thoroughly dry. Klein thinks that even the location of these bacilli in the lower part of the small intestine should of itself suggest suspicion, inasmuch as bacilli and micrococci in great numbers are contained in it even in health, and the more because this locality is not the exclusive seat of the disease. More conclusive evidence, however, was collected by him in India. For instance, three of the houses situate in a certain street in Calcutta contained in all eight cases of cholera. Leading out of the street was a narrow lane to a large water-tank, around which was built a squalid rookery. The water of this tank was used in the rookery for all purposes, and contained the comma-bacilli. Now, the houses in the street were not supplied with water from the tank, and yet eight cases of cholera occurred in the square, while none were found in the rookery, which was inhabited by about 200 families. The English Cholera Commission has also found a bacillus apparently similar with the cholera. bacillus in the intestines of children and adults suffering from diarrhoea. Dr. Lewis, of Netley, has found the same in the saliva of healthy persons. With regard to the evacuations containing the virus, Dr. Klein found that in India many of the publicbuilt wells were contaminated by sewage, and that tle water, though nominally not used for drinking purposes, for exfediency was generally so used, and especially at night time. $\Lambda$ gain, at Benares a large sewer opens into the Ganges at a spot where the pilgrims and natives perform their religious ablutions, these including especially the washing out of the mouth with the river water. In spite of this only sporadic cases of cholera occur. Dr. Klein has been led to the conclusion with regard to the cholera-that Koch's bacillus cannot be the cholera germ.

\section{SCIENTIFIC SERIALS}

American Journal of Science, March.-Prof. Marsh's monograph on the Dinocerata, by L. P. B. This valuable contribution to American palrontology forms a sequel to the author's 
work on the Odontornithes, or birds with tecth, and contains a full account of the peculiar order of mammals discovered by him during the last fifteen years in the early tertiary formations of the great central plateau in Wyoming. The old lacustrine basin of this region, where alone the remains of Dinocerata have hitherto been found, have already yielded parts of over 200 individuals, which are now grouped in three genera: Dinoceras, Marsh; Tinoceras, Marsh; and Uintatherium, Leidy. The last-named appears to be the most primitive type, and Tinoceras the most specialised, Dinoceras being intermediate. Of specics the number cannot yet be determined, but thirty more or less distinct forms have already been recognised. In stature and movements it appears to have resembled the elephant as much as any other known type, differing from it especially in the shape of the skull, remarkably small brain, longer neck, and more bent fore limbs. It was by far the largest of all known Eocene animals. The paper is enriched with numerous illustrations, and with a map showing the region of Dinoceras beds.On Taconic rocks and stratigraphy, with a geological map of the Taconic region, by lames D. Dana. In this paper the author embodies the results of a fresh study, begun in 1882 , of the Taconic region extending over parts of Massachusetts, Connecticut, Vermont, and New York. The rocks described comprise the Taconic skirts of the Taconic range, and subordinate ridges within the adjoining limestone arca; the limestone formations on the east and west sides of the Taconic range; and the quartzite adjoining or within the limestone area. All these rocks are regarded as belonging to one system of Lower Silurian age, with the Taconic schists as the upper member of the serics. The map is to a scale of half an inch to the mile.Variations of latitude, by Asaph Hall. The author deals with Signor Fergola's recently-proposed plan for investigating variations of latitude by special series of observations made with the best prime vertical transit instruments on selected lists of stars. A chief feature of the plan is that the work is to be mainly differential, two observatories under the same or nearly the same latitude co-operating. - Notes on the Jurassic strata of North America, by Charles A. White. The paper is mainly a reply to the objections raised by $\mathrm{Mr}$. J. F. Whiteaves, of the Caniadian Geological Survey against the classification of certain exposed formations frequently occurring throughout Colorado, Wyoming, Dakota, Utah, and Montana, and usually referred to the Jurassic period.-Meteoric iron from Coahnila, Mexico, by M. T. Lupton. An analysis of a fragment of this meteoric mass, weighing about $192 \mathrm{lbs}$, yielded : iron, $9 \mathrm{I} \cdot 86$; nickel, 7.42 ; cobalt, 50; phosphorus, 27. - Optical projection of acoustic curves, by W. Le Conte Stevens. Optical prescntations of a concord and a discord are shown projected on a screen by a simple and ingenious process.-Measurement of strong electrical currents, by John Trowbridge.-Divisibility of the Archacan formations in the North-West, by R. D. Irving. The region here investigated occupies, as indicated by the accompanying sketch-map, a tract some sixty miles in length between Lake Numakagon, in North Wisconsin, and Lake Gogebic, in North Michigan. The Archxan rocks of this district are referred to the IIuronian and Laurentian systems.-Mineralogical notes, by W. I. Hidden. Specimens are described of phenacite and Xemotine, from new localities; of Fayalite, from Colorado of Zircon, from Canada; and of zutile and emeralds, from North Carolina.

Nachrichton won der K. Gesellschaft der. Wissenschafien und der Universitül wu Göttingen, August to December, 1884.-A contribution to the theory of the absorption of light in crystals, by W. Voigt. - Remarks on the theory of the cycloid and on all forms of cycloidal curves, by A. Enneper.-Researches on the symmetrical relations and elasticity of crystals, by B. Minnegerode. On the histolugy of the Asterida, by Dr. Otto Hamann. - On some derivatives of urca, by $R$. Lenckart.-On the preparation of orthodinitrobenzol in large quantilies, by Paul Jannasch. - A contribution to the theory of complex dimensions developed from $n$ unities, by $\mathrm{K}$. Weiersirass.-Researches on the optical structure and propertics of leucitc, by C. Klein. -On some noteworthy archæological object in Treves, by Friedrich Wieseler.-Remarks on Gauss's algebraic series, by J. Thoma.-On the titrimetric analysis of urea, by Dr. Th. Pfeiffer-On the development of the reproductive organs in limax agrestis, by I. Brock.--On the classification of the genus Loligopsis, Lam. (Leachia Lesucur), by J. Brock.-Remarks on the Aita Mathenatica, edited by Dr. Gösta Mittag-Lefler, by
Ernst Schering. - On the elcctro-magnetic rotation of a fluid, by Eduard Riecke. - On the inflexion of the present participle and comparative in Moso-Gothic, by Leo Meyer.

\section{SOCIETIES AND ACADEMIES LONDON}

Royal Society, March 19.- "On 'Transfer-resistance' in Electrolytic and Voltaic Cells." By G. Gore, LL.D., F.R.S.

The existence of this phenomenon has been a matter of doubt ever since the year 1831 , and the question has been examined by many investigators. In the present paper are described a series of methods by means of which its reality has been determined. Other methods are given for measuring the amounts of such "resistance," either collectively at the two electrodes of an clectrolytic cell, or separately at each electrode. Modes of obviating the interference of polarisation, and of securing success in the measurements, are also describert.

The influence of various circumstances upon the phenomenon were investigated-viz. strength and density of current; total resistance ; density of current and size of electrode ; composition of the elcctrolyte ; strength of ditto; combined electrolytic cells; temperature; and chemical corrosion. The relations of the phenomcnon to size of plate in voltaic cells, to the positive and neyative plates respectively, and to strength of current in those cells, were also examined, and the results are given.

The following are the chief facts established by this research :That a specics of electric "resistance," distinct from that of polarisation and of ordinary conduction-resistance, varying greatly in amount in different cases, exists at the surfaces of mutual contact of metals and liquids in electrolytic and voltaic cells. That this "resistance" varies largely in amount with different metals in the same solution, and with the same metals in different solutions; in dilute solutions of mineral acids of different strengths, or of different temperatures, and is usually small with easily corrodible metals which form quickly soluble salts, and large with those which are not corroded ; and is disguised in the case of those which by corrosion form insoluble salts.

The results of the experiments also show that the same voltaic current was "resisted" in different degrees by every different metal when employed as an anode, and when used as a cathode ; also by the same metal when used as an anode and cathode respectively ; and that the proportions of such "resistance" at an anode and cathode of the same metal varied with every different metal in every different electrolyte (and strength of electrolyte), and at every different temperature; and that the resistance at the anode was usually smaller than that at the cathode ; in some cases, however, where a film was formed upon the anode, an apparently reverse effect occurred; that a current from a given positive plate of a voltaic cell was differently resisted by evcry different metal used as a negative plate in that cell ; and that by rise of temperature "transfer-resistance" was usually and considerably reduced.

They further show that this species of "resistance" was largely reduced by increasing the strength of current; and was thus conspicuously distinguished from ordinary conductionresistance of the electrolyte. In conscrutence of this effect, "transfer-resistance" was greatly influenced by every circumstance which altered the ordinary resistance, and thereby the strength of current. The usual effect of diminishing the density of current alone, by enlarging both the electrodes and keeping the strength constant, was to diminish the "transfer-resistance;" and of cnlarging one only, was to diminish it at that electrode and increase it at the other, the effect being greatest at the altered electrode; but the influence of density was very much smaller than that of strength of current. The current was usually less "resisted," and larger with a small positive plate and a large negative onc, than with those sizes reversed. Alterations of size or kind of metal at one plate of an electrolytic or voltaic cell affected the "transfer-resistance" at the other, by altering the strength and density of the current.

"Transfer-resistance," therefore, appears to vary, not only with every physical and chemical change in the metals and liquids, but also with every alteration in the current. Sucb "resistance" throws light upon the relative functions of the positive and negative plates of voltaic cells, and illustrates the comparatively small influence of the negative one in producing strength of current. Nearly all these conclusions arc based upon results represented by average numbers obtained by series of experiments. 